\title{
Moje żydostwo*
}

Do wspomnień, których nie mogę wymazać z pamięci, należą uroczystości chrześcijańskie, przede wszystkim bożonarodzeniowe pasterki. Przy odrobinie wysiłku byłbym jeszcze nawet w stanie wyrecytować katolickie wyznanie wiary. Jak w takim razie, jakim prawem mogę w tych okolicznościach mówić o „moim żydostwie"? Przecież ono wcale nie istniało. Miałem dziewiętnaście lat, kiedy w Wiedniu, moim rodzinnym mieście, gdzie w równej mierze rzucił nas los, co zostaliśmy wydaleni z prowincji górnoaustriackiej, dowiedziałem się o istnieniu języka jidysz. Natomiast mieszkająca $\mathrm{z}$ nami siostra mojej matki, również wdowa po poległym żołnierzu, często zapewniała, że będzie modlić się za mnie do swego ulubionego św. Antoniego, który rzekomo zawsze przychodzi z ratunkiem w skrajnie trudnych sytuacjach. Co takiego musiało wydarzyć się, że śmiem dzisiaj mówić o „moim żydostwie”, że nie tylko teraz, lecz przy każdej nadarzającej się okazji mówię: jestem Żydem?

Mój ojciec przyszedł na świat w Hohenems, w austriackim landzie Vorarlberg jako Żyd [Volljude]. Nie znałem go, ponieważ urodziłem się w 1912 roku, a on dwa lata później zaciągnął się do tyrolskiego pułku strzelców cesarskich w armii monarchii austro-węgierskiej. W 1916 roku poległ na wojnie. Kiedy usiłuję zrekonstruować jego żydostwo, maluje się przede mną niewyraźny obraz. Zdaje się, że niewiele wagi przykładał do wspólnoty wyznaniowej, do której oficjalnie przynależał. Już jego ojciec, czyli mój dziadek, w dużej mierze oddalił się od żydowskich korzeni.

Bardziej skomplikowany okazał się przypadek mojej matki: była chrześcijanką, jednak nie „czystej rasy aryjskiej”, jak się później dowiedziałem. Wielokrotnie w ciągu dnia przysięgała na Jezusa, Maryję i Józefa, co w miejscowym dialekcie brzmiało mniej więcej: Jessasmarandjosef. Do kościoła chodziła rzadko,

* Przekład za zgodą wydawcy na podstawie: J. Améry: Werke. Hrsg. I. Heidelberger-Leonard. Bd. 7: Aufsätze zur Politik und Zeitgeschichte. Hrsg. S. Steiner. Stuttgart 2005; ( 1978, 2005 Klett-Cotta - J.G. Cotta'sche Buchhandlung Nachfolger GmbH, Stuttgart. 
właściwie tylko przy okazji ważniejszych świąt. Modlitwa, której mnie nauczyła, była krótka: „Panie Boże, daj mi wiary, ile trzeba, abym trafił do nieba”. Odklepywałem ją przed zaśnięciem może do dziewiątego roku życia, po czym przestałem - nie była mi więc dana wiara, a bramy niebios się przede mną zamknęły. Od czasu do czasu matka używała słowa nebbich ${ }^{1}$ i było to jedyne żydowskie słowo, jakie słyszałem $\mathrm{z}$ jej ust. Powodów dla wypowiadania zarówno Jessasmarandjosef, jak i nebbich w naszym domu nigdy nie brakowało: należeliśmy, nebbich, do klasy średnioproletariackiej i ani Jezus, ani Maryja, ani nawet Józef nie chcieli się nad nami zmiłować. W domu nie mówiło się o Żydach, choć wiedziałem wszystko o swoim pochodzeniu. Nic przede mną nie ukrywano, po prostu sprawy żydowskie nie były tematem rozmów.

Po przeprowadzce z prowincji górnoaustriackiej do Wiednia, gdzie antysemityzm był faktem, a swastyka zagrożeniem, rozpoczął się dla mnie proces nauki. Czytałem wszystko, co tylko udało mi się zdobyć: od Langbehna ${ }^{2}$, przez Moellera van den Brucka ${ }^{3}$, aż po Hansa Blühera ${ }^{4}$, Houstona Stewarta Chamberlaina $^{5}$, nawet - pożal się Boże - walczącego z „kajdanami zysku” Gottfrieda Federa $^{6}$, Mit XX wieku Rosenberga ${ }^{7}$, a także Mein Kampf Hitlera. Wszystkie

${ }^{1}$ Zarówno etymologia, jak i znaczenie słowa nebbich są niejednoznaczne, ponieważ partykuły tej używano głównie w języku mówionym. W zależności od kontekstu nebbich zazwyczaj wyrażało ubolewanie („niestety”, „szkoda”, „uchowaj Boże!”) lub określało godną pożałowania osobę. Możliwe, że słowo to wywodzi się z polskich zwrotów „nieboga!” lub „niebożę” [wszystkie przypisy pochodzą od tłumaczki].

2 Julius Langbehn (1851-1907) - niemiecki pisarz i krytyk kultury, nacjonalista i antysemita; największą popularność przyniosła mu książka Rembrandt als Erzieher (1890). Głoszone przez niego idee miały istotny wpływ na rozwój antysemityzmu w Niemczech.

${ }^{3}$ Arthur Moeller van den Bruck (1876-1925) - niemiecki historyk kultury, publicysta nacjonalistyczny, prekursor myśli narodowosocjalistycznej. W 1923 r. ukazała się jego najważniejsza książka Das dritte Reich.

${ }^{4}$ Hans Blüher (1888-1955) - niemiecki pisarz i filozof, przed drugą wojną światową znany z działalności w nacjonalistycznym ruchu Wandervogel (Wędrowne ptaki). W czasach narodowego socjalizmu wycofał się z życia publicznego i pracował nad swym najważniejszym dziełem: Die Achse der Natur (1949). Wielokrotnie zarzucano mu poglądy antysemickie, czemu on sam stanowczo zaprzeczał.

${ }^{5}$ Houston Stewart Chamberlain (1855-1927) - angielski filozof kultury, publicysta, germanofil. Był prekursorem darwinizmu społecznego i przeciwnikiem Kościoła katolickiego. Jego najbardziej znane dzieło to Die Grundlagen des XIX Jahrhunderts (1899), w którym propagował antysemicki punkt widzenia, występując z twierdzeniem o wyższości rasy aryjskiej.

${ }^{6}$ Gottfried Feder (1883-1941) - niemiecki ekonomista i wiodący członek NSDAP w początkowym okresie jej istnienia, uczestnik puczu monachijskiego. W 1919 r. napisał Manifest o zerwaniu kajdanów zysku. Był doradcą Hitlera w sprawach finansowych i ekonomicznych, znany $\mathrm{z}$ antysemickich publikacji, m.in. Walka ze światowa finansjera (1933).

7 Alfred Rosenberg (1893-1946) - ideolog narodowego socjalizmu, minister Rzeszy ds. Okupowanych Terenów Wschodnich, twórca najważniejszych teorii rasistowskich, w tym skrajnego antysemityzmu, które wyłożył w Micie XX wieku (1930). W wyniku procesów norymberskich został skazany na śmierć i powieszony. 
te obrzydliwości pochłaniałem ze skrajnie ambiwalentnymi uczuciami: z jednej strony powoli uświadamiałem sobie, że ludzie ci intelektualnie uczynili wszystko, żeby mnie i podobnych do mnie zniszczyć (czytałem z nienawiścią i wrogim wzburzeniem!), z drugiej strony chciałem za wszelką cenę pozostać „obiektywny”, tłumiłem więc w sobie palącą od środka wściekłość i narzucałem intelektualną oziębłość - dawno już zrozumiałem, że nie była ona niczym innym, jak elementem psychicznego wyparcia. Straszliwa éducation sentimentale dla młodego Żyda... Żyda? Właściwie tak, gdyż z wolna zacząłem pojmować, że traktuję siebie samego jako Żyda, choć z woli przypadku i otoczenia rzadko miewałem kontakt z „prawdziwymi”, w pełni świadomymi swoich problemów i politycznie czujnymi Żydami. Czy unikałem ich towarzystwa? Szczerze powiedziawszy, nie pamiętam. Wszystko to tkwi głęboko w odmętach przeszłości i nie potrafię już stwierdzić, co w moim zachowaniu społecznym było wtedy półświadomym wyborem, a co przeznaczeniem. Dzisiaj myślę, że całą moją strukturę duchową jako dziewiętnastolatka wciąż jeszcze kształtowała duszna prowincja.

Latem 1932 roku - kiedy w Niemczech Papen był już u władzy, a w Austrii wisiało nad nami niebezpieczeństwo klerofaszyzmu - wydarzyło się coś, co zaważyło na całym moim życiu i było istotniejsze niż wszystkie dobre oraz złe lektury, niż cała moja bezradność i prowincjonalność. Zakochałem się w dziewczynie, która później została moją pierwszą żoną. Miała charakterystyczną dla rudowłosych śnieżnobiałą cerę delikatnie pokrytą piegami, malutki spiczasty nos, piękne duże usta i nieskazitelne zęby. Ta osiemnastolatka pochodziła z Grazu i mówiła dialektem zbliżonym do mojego. Nosiła typowe austriackie stroje ludowe, tzw. dirndle, w których wyglądała wyjątkowo pięknie. Mój świat się zawalił, kiedy okazało się, że nie ma czysto styryjskiego pochodzenia, lecz jest „wierzącą Żydówką”, a jej ojciec należał do napływowych Żydów ze Wschodu. „Ta dziewczyna to polska Żydówka”, powiedziała matka, która i bez tego każdą kobietę pojawiającą się w moim życiu traktowała jak wstrętnego intruza. Mimo sprzeciwu matki nie porzuciłem mojej jasnoskórej dziewczyny, lecz zacząłem ignorować jej pochodzenie. Oczywiście, cały czas chciałem zostać antynazistą, jednak z własnej, nieprzymuszonej woli: do wzięcia na siebie losu żydowskiego nie byłem jeszcze gotowy. Dlaczego? Podczas lektury tak wielu narodowosocjalistycznych dzieł wbiłem sobie do głowy obraz samego siebie jako wroga i w pełni go uwewnętrzniłem - tak jak później przedstawił to Sartre w niedoścignionych Rozważaniach o kwestii żydowskiej ${ }^{8}$. Chciałem być wrogiem nazistów, dlatego $\mathrm{z}$ młodzieńczym zapałem wikłałem się w bójki, do których stale dochodziło wtedy na wiedeńskim uniwersytecie. Pragnąłem jednak, żeby działo się to za sprawą mojego własnego wyboru, a nie ze względu na „krew” czy też „rasę”. Tak oto - mniej więcej w tym samym czasie,

\footnotetext{
${ }^{8}$ J.-P. SARtre: Rozważania o kwestii żydowskiej. Tłum. J. Lisowski. Warszawa 1957.
} 
kiedy porzuciłem dzieła Carossy ${ }^{9}$ i coraz chętniej sięgałem po Feuchtwangera ${ }^{10}$ - opanowałem do perfekcji sztukę mimikry, której w gruncie rzeczy wcale nie potrzebowałem, bo wszystko przecież wskazywało na moją żałosną rdzenność. Byłem blondynem o niebieskich oczach, którym doskonale potrafiłem nadać groźny wyraz. Mój ewidentnie żydowski nos - odziedziczony w prostej linii po dziadku - nie zdążył jeszcze wówczas nabrać jednoznacznie ostrych rysów, które na szczęście z czasem zyskał i które mnie naznaczyły.

Tak naprawdę znalazłem się w sytuacji psychicznie nie do zniesienia: zostałem wychowany jako chrześcijański Austriak - a jednak wcale nim nie byłem. Już nim nie byłem. Przytłaczająca większość nie tylko niemieckiego, ale też mojego, austriackiego społeczeństwa wykluczyła mnie ze wspólnoty. Już wówczas powinienem to zaakceptować - gdybym tylko był gotów powiedzieć sobie prawdę. Ale właśnie: czym była owa prawda? Czy kryła się w powtarzanym przez matkę Jessasmarandjosef, we wspomnieniach pasterki i mszy świętej, w moim dialekcie, $\mathrm{w}$ austriackim prowincjonalnym pochodzeniu dziadka czy może w moim żydowskim nosie? Teraz, kiedy nad tym rozmyślam, nie pozostaje mi nic innego, jak cofnąc się do tej odległej przeszłości i zrewidować ją, przyznając się do żydowskiego nosa. I to w bardzo konkretnym znaczeniu. Wiem, że słowo „rasa” jest dzisiaj potępiane. Jednak tylko głupiec może zaprzeczyć temu, że rasy ludzkie istnieją, manifestując się zarówno we właściwościach fizycznych (ciemny, jasny, różowawy kolor skóry etc.), jak i tych psychicznych oraz intelektualnych. Nie posiadam na to żadnych dowodów i zdaję sobie sprawę, że współcześni biolodzy nie poparliby mojej tezy. Czy jednak doświadczenie długiego życia nie znaczy w ostatecznym rozrachunku więcej niż kilka kontrowersyjnych i nazajutrz być może nieaktualnych hipotez, popartych wynikami badań w najlepszych laboratoriach? Jestem pewien - i pewności tej nie zachwieje żadna antropologiczna teoria - że mój intelekt i duchowe usposobienie są żydowskie nie tyle ze względu na wychowanie czy środowisko, które w moim przypadku miały z żydowskością niewiele wspólnego, ile ze względu na urodzenie. I teraz każdy, kto chce, może nazwać mnie podłym „rasistą"!

Za bardzo jednak wyprzedziłem fakty. Jedna rozstrzygająca dla mnie data nie może zostać $\mathrm{w}$ tym miejscu pominięta: rok 1935. Ustawy norymberskie, o których istnieniu dowiedziałem się w jednej z wiedeńskich kawiarni i których treść znałem później niemalże na pamięć, uświadomiły mi w końcu z całą wyrazistością, że dla nazistów - nie tylko tych w pełni zaangażowanych, lecz

${ }^{9}$ Hans Carossa (1878-1956) - niemiecki pisarz, poeta i autor opowiadań. Po objęciu władzy przez nazistów wybrał drogę tzw. wewnętrznej emigracji. Mimo dystansu i krytycznego (choć nie do końca konsekwentnego) stanowiska Carossy wobec reżimu narodowosocjalistycznego naziści wielokrotnie próbowali instrumentalizować jego dzieła.

${ }^{10}$ Lion Feuchtwanger (1884-1958) - niemiecki pisarz żydowskiego pochodzenia, krytyk teatralny, eseista i publicysta, współzałożyciel wydawanego na emigracji czasopisma „Das Wort”. W swoich dziełach często dawał upust wrogiemu stosunkowi do nazistów. 
bardziej nawet dla większości przeciętnych Niemców i Austriaków - stałem się Żydem lub, jak to się wówczas mówiło, „uchodziłem za Żyda”. Swego czasu zacząłem nawet czytać Historię Żydów Heinricha Graetza, ale szybko mnie znudziła. Muszę przyznać, że do dzisiaj niewiele zmieniło się w tym względzie. Moja znajomość Biblii ogranicza się do tetralogii Thomasa Manna o Józefie. Posiadam wiedzę historyczną na poziomie przeciętnego Europejczyka, którego określa się mianem „wykształconego”, lecz który jest przy tym, jak kiedyś znakomicie powiedział o sobie Robert Musil, „wszechstronnie niewykształcony”. Oznacza to, że mój ogólny obraz historii zawiera olbrzymie luki, których nigdy nie starałem się porządnie zapełnić. Do nich właśnie należą dzieje narodu wybranego. Jeden jedyny raz w życiu, we francuskim obozie dla internowanych $\mathrm{w}$ pirenejskim Gurs podczas straszliwej zimy 1940/1941 roku, uczestniczyłem w święcie Chanuki obchodzonym przez ortodoksyjnych Żydów. Słuchając ich przejmującego śpiewu stopniowo przechodzącego $\mathrm{w}$ cierpiętniczy krzyk, poczułem się tak, jakbym nagle znalazł się w zupełnie innym i obcym dla mnie świecie. Towarzyszył mi filozof Georg Grelling ${ }^{11}$. Spoglądaliśmy na siebie oniemiali i niestety również odrobinę zawstydzeni. Ten elegancki mężczyzna z Berlina odchrząknął i powiedział z zażenowaniem: „Czuję się jak w skansenie”. Jeśli, jako ateista, w ogóle rozważam fenomen religii (chociaż słowo „rozważać” jest w tym kontekście użyte na wyrost), to tym, co wzbudzało we mnie zainteresowanie, było zawsze chrześcijaństwo. W gruncie rzeczy jest to całkiem zrozumiałe, ponieważ bycie „chrześcijaninem” nie oznacza tylko wiary w Boga i jego Syna. Podobnie jak bycie krytycznym chrześcijaninem nie wiąże się wyłącznie z objaśnianiem teologicznych problemów - to raczej partycy pacja w naszej kulturze. Ecclesia istniała dla mnie od zawsze, synagoga była czymś obcym. Dlatego właśnie nie mogę mówić o moim „żydostwie” [Judentum]. Proponuję w zamian inne pojęcie, które według mnie ma zdecydowanie większą wagę i do którego stanowczo, choć bezwyznaniowo, się przyznaję, a mianowicie: „bycie Żydem” [Judesein]. Chronologicznie wiąże się to $\mathrm{z}$ wydarzeniami, o których pisałem wcześniej. W 1935 roku poznałem i już na zawsze uwewnętrzniłem ustawy norymberskie. Uświadomiłem sobie wówczas znaczenie mojego „bycia Żydem”, które w wyniku późniejszych straszliwych doświadczeń uległo wprawdzie stopniowej intensyfikacji, jednak jakościowo właściwie się nie zmieniło. Społeczeństwo chciało mnie jako Żyda, a ja musiałem przyjąć jego wyrok. Odwołanie się do sfery subiektywnych uczuć, zgodnie z którą mógłbym powiedzieć, że nie „czułem się” Żydem, byłoby dziecinnym i nic nieznaczącym zagraniem. Dopiero dziesięć lat później przeczytałem u Sartre’a, że Żyd to człowiek, którego inni za takiego uważają. Dokładnie tak było w moim przypadku.

${ }^{11}$ Améry miał zapewne na myśli Kurta Grellinga (1886-1942) - niemieckiego matematyka, logika i filozofa, związanego z Kołem Wiedeńskim i empiryzmem. Podobnie jak Améry uciekł on do Belgii, gdzie został internowany, potem najprawdopodobniej zamordowany w Auschwitz. 
Kiedy nagle przyszedł dzień 11 marca 1938 roku - to znaczy z chwilą, gdy mój własny kraj z radością rzucił się na szyję Führerowi potężnej niemieckiej Rzeszy niczym rozochocona i stęskniona psina - ja byłem już uzbrojony. Jedyną przeszkodą do pokonania była moja matka. W zanadrzu miała już gotowy, potajemnie uknuty plan. Jej pierwszy narzeczony, mężczyzna nieskazitelnie aryjski, gotów był przysiąc, że naprawdę jestem jego synem, a nie mojego żydowskiego ojca. Resztą miał zająć się przyjaciel domu piastujący wysokie stanowisko w Urzędzie do spraw Polityki Rasowej, tzw. Sippenamcie. Ja miałem tylko jak najszybciej załatwić pewną drobnostkę, a mianowicie rozstać się z moją żydowską dziewczyną, którą wcześniej zdążyłem poślubić. Do dzisiaj zadaję sobie pytania, na które nie znajduję odpowiedzi: czy przystałbym na propozycję matki, gdybym nie był tak silnie związany z tą Żydówką, która dzięki swojemu dialektowi mogłaby z powodzeniem występować $\mathrm{w}$ reklamie biura turystycznego Ostmark? Czy opuściłbym ten kraj - bez przymusu, niczym emigrant z pobudek światopoglądowych, gdybym dumnie powiedział wtedy: „Zgoda”? Jak bardzo jednak kłócą się ze sobą uczciwość i duma! Jedna wyklucza drugą i dlatego nie pozostaje mi nic innego, jak powiedzieć sobie: nie wiem, co by było, gdyby... Wówczas nie znałem jeszcze pojęcia „autentyczność”, które upowszechniło się dopiero po wojnie. Podświadomie już chyba jednak przeczuwałem, że człowiek nie jest w stanie żyć w totalnym, obejmującym całą osobowość, kłamstwie. Ukonstytuowałem się jako Żyd. Jednak cały czas pojawiały się przeszkody, których nie potrafiłem zaakceptować. Na przykład pod żadnym pozorem nie chciałem, żeby w dokumentach wpisano mi obowiązkowe imię "Izrael”. Nie wyrobiłem sobie paszportu, ponieważ przybito by w nim stempel z czerwoną literą „J”.

W Antwerpii, gdzie zrobiliśmy pierwszy przystanek podczas ucieczki, zaopiekował się nami Joodse Komiteit. Ktoś, kto nigdy nie żył wśród Żydów, znalazł się nagle w otoczeniu samych Żydów, którzy nie mieli w głowach nic innego - społeczeństwo już o to zadbało! - poza własną żydowskością. Była to, jak mówiło się w ówczesnym żargonie, „wspólnota losu”, a także „wspólnota ludu”. Przetrwała, ponieważ bogata antwerpska gmina żydowska troszczyła się o nas jak o własne dzieci. Osobiście jednak - co było równie paskudne, jak niemądre - często reagowałem na otaczającą mnie wspólnotę skrajną irytacją. Dochodzący do moich uszu ze wszystkich stron jidysz wzbudzał we mnie niepomierne zażenowanie. „Bycie Żydem” przyjąłem wprawdzie jako zasadę, jednak w codziennym życiu nie zdawałem egzaminu. Niejasno przeczuwałem wówczas, że będę musiał jeszcze przejść przez zupełnie inne, dużo cięższe szkoły, żeby naprawdę zostać tym, kim byłem: Żydem. Nauczyciele i mistrzowie byli już w drodze.

10 maja 1940 roku, podczas niemieckiej ofensywy na Zachodzie, zostałem aresztowany jako „obywatel państwa niemieckiego” i uznany za wrogiego obcokrajowca. Wywieziono nas w głąb południowej Francji. Na próżno usiłowaliśmy przekonać belgijskie i francuskie oddziały straży, że nie jesteśmy wrogami aliantów, lecz emigrantami. Nie jesteśmy Niemcami, lecz Żydami. Nic nie pojmowali. 
Żydzi? Ale co to znaczy? To przecież religia. Léon Blum też jest Żydem, mówili. Z Blumem nie mieliśmy nic wspólnego - byliśmy dla nich des boches ${ }^{12}$. Kiedy jednak po sześciu tygodniach Francja została pokonana, nagle umysły Francuzów zaczęły się w niemalże baśniowy sposób rozjaśniać. Prawdziwi boches, czyli Niemcy znajdujący się pod pieczą komisji rozejmowych Hitlera, zostali uwolnieni, a Francuzi ze skrajnie odrażającym serwilizmem podziwiali ich jako zwycięzców. Natomiast my, inni - uchodźcy, których nie chciano w Rzeszy - błyskawicznie staliśmy się już nie tylko wrogimi, ale i uciążliwymi obcokrajowcami oraz przede wszystkim Żydami: w pełni niemieckim, rasistowskim znaczeniu tego słowa. Sale juif zajęło miejsce obraźliwego sale boche. Wydawało mi się wówczas - i nie byłem osamotniony w tych poglądach - że w przeciwieństwie do powierzchownego "antibochisme” niechęć do Żydów tkwiła w dużo głębszych warstwach osobowości Francuzów. Z każdym dniem coraz silniej odczuwałem, że narzucone mi przez społeczeństwo „bycie Żydem” nie było fenomenem typowo niemieckim. Nie tylko naziści uczynili ze mnie Żyda. Uważał mnie za niego cały świat, a ja byłem gotów zrobić to, co Sartre określał później mianem assumer, czyli w wolnym i niedoskonałym tłumaczeniu: „wziąć-na-siebie”. Zmusiłem się do odczuwania solidarności z każdym Żydem. Już raz byliśmy zamknięci w getcie i nie różniło się ono od tego, w którym świat zamknął dzisiaj państewko Izrael.

Wkrótce zmienili się nauczyciele. Po tym, jak uciekłem z obozu i pieszo przemierzyłem pół Francji, aby dotrzeć do ukochanej kobiety w okupowanej przez Niemców Belgii, zniknęli szykanujący nas w obozie dla internowanych w Gurs brutalni, acz niegroźni żołnierze francuskiej armii Garde Mobile. Ich miejsce zajął mistrz, co rodem jest z Niemiec. Dzisiaj myślę, że dołączenie do ruchu oporu, do którego przyłączyłem się w najskromniejszej ze wszystkich funkcji, pozbawionej jakichkolwiek gestów heroizmu, mogło być nieświadomie powziętą, ostatnią próbą uwolnienia się od żydowskiego losu, który intelektualnie już dawno na siebie wziąłem. Żydów przepędzano, wystawiano, aresztowano i deportowano wyłącznie dlatego, że byli Żydami. Z perspektywy czasu wydaje mi się, że chciałem zostać wtedy schwytany przez wroga nie jako Żyd, lecz jako członek ruchu oporu. Ostatnia, absurdalna próba ucieczki przed zbiorowym losem. Z narażeniem życia roznosiłem bezskuteczne ulotki, ale towarzyszyła mi fałszywa i dumna świadomość, że jestem „bojownikiem” i nie należę do tych, którzy jak beczące owce dają się prowadzić na rzeź.

Od razu po aresztowaniu dopadła mnie jednak rzeczywistość. Oficjele interesowali się mną dopóty, dopóki uważali mnie za niemieckiego dezertera, żołnierza, być może nawet oficera. Gdy moja tożsamość wyszła na jaw, potraktowali mnie jak śmiecia. „Sabotaż sił zbrojnych”, widniało w moich aktach i tak długo,

${ }_{12}$ Francuskie słowo boche jest pochodzącym z czasów drugiej wojny światowej pogardliwym określeniem Niemców; odpowiednikiem w języku polskim byłyby wyrazy: „szwab”, „szkop”. 
jak sądzili, że jestem renegatem, poddawali mnie drastycznym przesłuchaniom. Odkąd zdali sobie sprawę, kim jestem, przestałem się dla nich liczyć. Nie doszło do żadnego procesu. Z góry wydano na mnie wyrok śmierci, który brzmiał: Auschwitz. Co mogę dodać jeszcze do tego, co napisałem wcześniej w Poza wina i karą? Może tylko jedno: że w Auschwitz moje „bycie Żydem” przybrało ostateczną, trwającą po dziś dzień postać. Wprawdzie aresztowano mnie jako członka ruchu oporu, lecz w Auschwitz nosiłem taką samą żółtą gwiazdę i byłem takim samym Żydem, jak wszyscy inni, którzy nie mieli odwagi sprzeciwić się, nie mówiąc już o rozdawaniu antypaństwowych ulotek. Dopiero w tym piekielnym kręgu różnice rasowe stały się rzeczywiście odczuwalne i odciskały się na skórze jak wytatuowane numery, którymi nas naznaczano. Wszyscy „aryjscy” więźniowie znajdowali się $\mathrm{w}$ tej otchłani lata świetlne ponad nami. Tłukli nas, kiedy im się tylko podobało - szczególnie wyróżniali się w tym względzie Polacy, czego nie sposób zapomnieć ani pominąć milczeniem. Wszyscy oni uwewnętrznili system wartości Führera, ponieważ przystosowała ich ku temu tradycja. Być może przeznaczono ich do roli niewolników narodu panów - nas, Żydów, przypisano śmierci. Doszło do tego, że dawaliśmy się bić bez sprzeciwu. Jeden jedyny raz odpowiedziałem ciosem na cios, błędnie uznając, że odzyskam w ten sposób godność. Później zrozumiałem, że nie miało to sensu. Żyd był zwierzęciem ofiarnym. Musiał pić kielich goryczy - aż do najbardziej gorzkiego dna. Piłem go. I w tym właśnie wyrażało się moje bycie Żydem. Żydostwo było czymś innym, nic mnie z nim nie łączyło. Powoli zaczynałem rozumieć jidysz, ale nie czyniłem wysiłków, żeby go używać. Od czasu do czasu zdarzało się, że Żydzi ze Wschodu spotykali się i śpiewali w jidysz piosenki, których słowa rozumiałem tylko połowicznie. Pamiętam, że niezwykle się wzruszyłem, gdy kilku z nich zaczęło nucić syjonistyczną piosenkę z refrenem: „Iach fuhr a-haim, iach fuhr aheim". Aheim oznaczało dla nich Ziemię Świętą. Dla mnie słowa Heim, Heimat pozbawione były sensu. Nigdzie nie czułem się jak w domu. Byłem Żydem i chciałem/powinienem był nim zostać. Po powrocie do Belgii w 1945 roku zacząłem coraz bardziej interesować się kulturą francuską, zauroczył mnie Paryż, Jean-Paul Sartre stał się dla mnie kimś w rodzaju ojca, niemniej jednak przestałem wierzyć $\mathrm{w}$ asymilację. Jak mogłaby być jeszcze możliwa? Wcześniej nie byłem „zasymilowany”, choć bardziej niż ktokolwiek inny byłem "pełnym” Austriakiem. Mimo to nie uchroniłem się przed żydowskim losem. Jak więc teraz - zmartwychwstały, lecz opuszczony jak nigdy wcześniej - mógłbym sobie wmówić, że istnieje chociażby cień nadziei na to, aby zostać Francuzem? Nie chodziło o język, lecz o zniszczone, dawno już pożółkłe, ale wciąż negatywnie istniejące wspomnienia z dzieciństwa i młodości, które ukształtowały wprawdzie moją przeszłość, lecz już dawno straciły na aktualności i uniemożliwiały mi stworzenie nowej rzeczywistości. Nieustające wygnanie, które wybrałem, stanowiło jedyną autentyczność, na jaką mogłem sobie pozwolić - bycie Żydem zamknęło przede mną wszystkie inne możliwości. 
Żydostwa rozumianego natomiast jako tradycja historyczna i pozytywny fundament egzystencji nigdy nie posiadłem. Jedyna rzecz pozytywnie łącząca mnie z większością Żydów na świecie to solidarność z państwem Izrael, której od dłuższego czasu nie muszę traktować już jako obowiązku. Ani dlatego, że chciałbym w Izraelu zamieszkać - jest tam zbyt gorąco, zbyt głośno i zbyt obco pod każdym względem - ani dlatego, że zawsze popieram to, co się tam wyprawia. Odpychają mnie tendencje teokratyczne oraz religijnie ugruntowany nacjonalizm. W Izraelu byłem tylko raz, z krótką wizytą i najprawdopodobniej nigdy więcej tam nie wrócę. Mimo to czuję się z mieszkańcami tej fatalnej ziemi - z tymi, którzy zostali sami, opuszczeni przez świat - nierozerwalnie związany, chociaż nie mówię w ich języku i nigdy nie mógłbym przejąć ich stylu życia. Izrael nie jest dla mnie spełnieniem proroctwa, biblijnie umotywowanym roszczeniem terytorialnym czy Ziemią Świętą, lecz zbiorowiskiem ocalonych, tworem państwowym, w którym każdy mieszkaniec $\mathrm{z}$ osobna długo jeszcze obawiać się będzie o swoją kondycję psychiczną. Solidarność z Izraelem oznacza dla mnie dotrzymanie wierności zmarłym pobratymcom.

Wciąż od nowa usiłuję nabrać dystansu. Udaje mi się to jednak tylko częściowo. Jestem czujnym krytykiem polityki izraelskiej i nie zważając na utratę przychylności czy przyjaźni, z całą stanowczością publicznie odrzucam obecny rząd izraelski jako twór powstały z pobudek irracjonalno-szowinistycznych. Otwarcie przyznaję, że sprzeciwiam się Beginowi ${ }^{13}$ i wszystkiemu, za co odpowiada ten człowiek. Tam jednak, gdzie chodzi o sprawy najważniejsze i gdzie przeczuwam niebezpieczeństwo grożące temu rozpaczliwie walczącemu państewku, moje bycie Żydem (bez żydostwa, na które nie mogę się powoływać, gdyż go nie posiadam) okazuje się - mimo wszystko - czynnikiem decydującym. Opowiadam się za Izraelem - i nie przejmuję się, kiedy moi przyjaciele z lewicy nazywają mnie zdrajcą. Łatwo im mówić: wierność zasadom jest dziecinnie prosta. Ja mam utrudnione zadanie, ponieważ wierność losowi, za którą się opowiadam, nie łatwo zdefiniować, a kto się jej trzyma, musi porzucić wszystkie wygodne teorie i dogmatyczne podpory. Grunt pod stopami się chwieje. $\mathrm{Z}$ pomocą nie przychodzi ani Bóg, ani Marks. Najmniej zaś Hegel.

Jedyne, czego można, czego ja mogę się trzymać, to bezpośrednie doświadczenie. Kiedy Izrael, ziemia dla mnie bynajmniej nieświęta, znajduje się w stanie zagrożenia, wszędzie wokół widzę płomienie. I wołam: pali się! Wiem, mój krzyk nie znajduje posłuchu. Ci, którzy wyznają judaizm, odmawiają mi prawa do bycia wysłuchanym i konsekwentnie przy tym obstają. Natomiast ci, którzy osobiście i na własnym ciele nigdy nie doświadczyli zagrożenia, i tak nie będą słuchać. Nie mam im tego za złe, ponieważ ja sam nie rozmyślam każdego dnia o masakrze

${ }^{13}$ Menachem Begin (1913-1992) - kontrowersyjny polityk izraelski, działacz syjonistyczny, zwolennik terroryzmu. W latach $1977-1983$ był premierem Izraela i pierwszym prawicowym szefem rządu w tym kraju. W 1978 r. podpisał porozumienie z Egiptem, za co otrzymał Pokojową Nagrodę Nobla; w 1983 r. wycofał się z życia publicznego. 
ormiańskiej wyrządzonej przez Turków. Ludzie rozmawiają o polityce i historii, o wydarzeniach obiektywnych. Ja natomiast do samego najbardziej gorzkiego końca trzymam się własnych doświadczeń. Gdybym posiadał żydostwo, mógłbym szybko przekształcić to, czego subiektywnie doświadczyłem, w obiektywną i skończoną historyczność. Ta droga jest jednak przede mną zamknięta. Cztery ściany zacieśniają się, przestrzeń staje się coraz węższa. Bycie Żydem (którego nie wybrałem) bez żydostwa (na które ze względu na pochodzenie i środowisko mogę sobie pozwolić jedynie za cenę kłamstwa) przeradza się w stan ducha, który specjaliści określiliby zapewne mianem „neurotycznego”, a który ja nazywam - wyłącznie mnie przysługującą i towarzyszącą mi do końca moich dni - melancholią.

Tłumaczenie Katarzyna Kończal

Jean Améry (właśc. Hans Mayer; 1912-1978), austriacki pisarz żydowskiego pochodzenia. W 1938 roku wyemigrował do Belgii, gdzie aresztowano go za działalność $\mathrm{w}$ antynazistowskim ruchu oporu. Był więziony i torturowany $\mathrm{w}$ twierdzy Breendonk, następnie przebywał w obozach koncentracyjnych w Auschwitz, Buchenwaldzie i Bergen-Belsen. Po wojnie zamieszkał w Brukseli, gdzie pracował między innymi jako korespondent szwajcarskiej prasy. W 1955 roku zmienił nazwisko na francuskobrzmiący anagram Améry, choć pisał i publikował niemal wyłącznie w języku niemieckim.

Najważniejsze dzieło Améry’ego to zbiór esejów Poza wina i kara. Próby przełamania podjęte przez złamanego z 1966 roku (polskie wydanie ukazało się dopiero w 2007 roku w tłumaczeniu Ryszarda Turczyna), w którym rozprawia się z doświadczeniem obozu koncentracyjnego. Choć pisał również powieści (Lefeu oder Der Abbruch; Die Schiffbrüchigen), głównie znany jest jako intelektualista i eseista - w Polsce ukazały się jego zbiory O starzeniu się. Bunt i rezygnacja oraz Podnieść na siebie rękę. Dyskurs o dobrowolnej śmierci (w tłumaczeniu Bogdana Barana). W 1978 roku Améry odebrał sobie życie. 
Artykuły i rozprawy 
